\title{
THE MANAGEMENT OF INTELLECTUAL PROPERTY IN A ROMANIAN STATE UNIVERSITY WHERE RESEARCH REPRESENTS A STRENGTH
}

\author{
ȚîTU Aurel Mihail \\ Faculty of Engineering, "Lucian Blaga" University of Sibiu, Sibiu, Romania, mihail.titu@ulbsibiu.ro \\ OPREAN Constantin \\ Faculty of Engineering, "Lucian Blaga" University of Sibiu, Sibiu, Romania, constantin.oprean@ulbsibiu.ro \\ RÄULEA Andreea Simina \\ Faculty of Engineering, "Lucian Blaga" University of Sibiu, Sibiu, Romania, andreea.raulea@ulbsibiu.ro
}

\begin{abstract}
The transition to the knowledge-based economy and society requires adaptation to constant change that implies intellectual property as a multidimensional concept that continually leaves its mark on generations contributing to their well-being in obvious and undeniable ways. The main objective of this article was to assess the present level of the management of intellectual property in a state university in Romania displaying their strengths and weaknesses. The overall objective of the work is to analyze the state of the art in a Romanian state university in order to find solutions to the current problems that the Romanian scientific environment is facing. The conclusions drawn in the study converge in directions and proposals for improving the way in which the intellectual property is regarded and its management in the state universities of Romania.
\end{abstract}

Key words: management, intellectual property, intellectual property protection, quality management, intellectual property valorisation

\section{Introduction}

Globalization and the apparition of the knowledge-based society will manifest through new force fields, which will transform intellectual property in structure and function alike. In a context of nonlinear thinking, we could say that the intellectual property will no longer be a simple extension of a structure, but a revolutionary concept, which corresponds better to the new requirements. It is sufficient to think of how time and space regain new meanings through the explosive growth of the internet and satellite communications.

Therefore, an organizational culture focused on the management of intellectual property protection is the key to a success that facilitates change, causing a high flexibility of universities in the new era of communication and modern technologies, new development models that focus mainly on intellectual property assets.

For any society, young people represent the essential resource for development and they are also the engine of change, their evolution being particularly reflected in carrying out economic activities and technological innovations. Aspirations, ideals and their concepts and ideas are giving rise to numerous initiatives that have resulted in the creation of a future with long-term benefits. It is therefore imperative for universities to give greater importance to the field of intellectual property and its management whereas within them is developed and created the highest potential creator of intangible assets.

The motivation which stands behind addressing the protection of intellectual property management research is oriented at least in the following areas of interest: the interest of the research theme at the international level, the range of the concept of intellectual property rights in the contemporary period, the potential development of intellectual property assets, in which the management of intellectual property protection is a very important component, the academic competitive environment centered on research, which involves strong interactions with the external environment, the dynamics and complexity of scientific treatise, and, in equal measure, the economic implications attached, the increasing importance of intellectual property assets valorization that can grow economic value overall, whereas universities cannot only be identified with the granting of diplomas and educating the workforce but they correlate especially with the realization of innovations and new approaches. 
Regarding the current state of the art of the research field, intellectual property has become a fundamental element in the modern economy, and there are numerous studies aimed at analyzing its way of use [1, 2, 3, 4], but the empirical researches related to the management of intellectual property protection in the context of universities are reduced.

The importance of the research theme at micro and macroeconomic level is supported by the importance accorded in the contemporary period by researchers both nationally and internationally to intellectual property in general and intangible assets in particular.

\section{Intellectual property - general considerations}

Intellectual property as a whole, refers to creations of the mind such as inventions, literary and artistic works, symbols and images used in commercial activities.

Many authors have tried to find proper definitions for the concept of intellectual capital. We consider suitable Thomas A. Steward's point of view that considers intellectual capital to be "intellectualknowledge material, information, intellectual property, which can be used to create wealth" [5].

Intellectual property is a concept that needs to be looked at in close relation with the concept of intellectual capital. So, a summary of the evolution of the concept of intellectual capital is required. Studies that have turned attention to this concept can be localized in three of the most powerful areas of the world: Japan, The United States and Europe. In Japan, Hiroyuki Itami, in his paper "Mobilizing Invisible Assets" [6] published in 1980, points out that successful strategies of Japanese companies depend on intangible assets such as know-how, brand visibilities, customer databases, but also personnel, tangible and financial assets. It points out, in the same context, the importance of a strategy suitable to both the internal and external environment of the company. In the United States the economists Rumelt, Wemerfelt, Penrose formulated different theories on the operation of commercial firms which have been crystallized by David Treece, from the University of Berkeley, via a reference article concerning the production of value through innovation. In Europe, Karl Erik Sveiby through "The Know-how Company" and "Knowledge Management" treats the human dimension of intellectual capital and valorization potential of an enterprise based on the competence and knowledge held.

Based on these approaches, a series of visions have been developed, with respect to an efficient use of the resources of an organization. A simplistic view of the process of exploiting intellectual property can be seen in Figure 1.

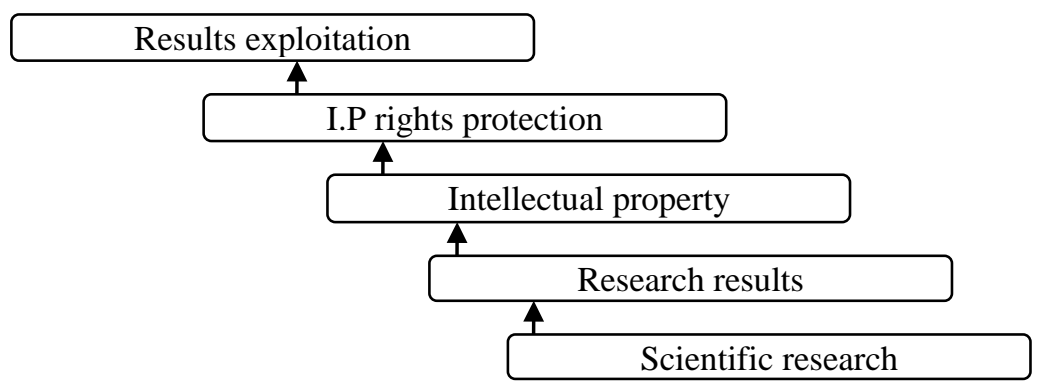

Figure 1: The process of capitalizing intellectual property

Nowadays the strategies of the organizations are made considering the intellectual capital and the struggle for survival that is given in a strong globalized market, where the only constant is the change. In this regard, the organizations that are considering a successful future are trying to capitalize on all the resources available to them to ensure this and choose increasingly to exploit the intellectual property rights held by them.

The importance of research and intellectual property is highlighted also at the European level through the Lisbon strategy, launched in 2005, regarding research, development and employment, which sets out a coherent policy and reforms designed to make the current European regulations more open to innovation. The main objective set out in this strategy has been to increase the expenditure on research/development to 3\% of GDP, at the level of Member States. Research thus became crucial for the sustainable development of the EU member countries.

Within the framework of the innovation strategy in the European Union, drawn up by the European Commission, education is regarded both as a pre-requisite to innovation production and as a priority direction for action. The innovation framework strategy specifies the need for Member States to 
significantly increase public spending for education and to identify and to tackle obstacles in the national education systems which hinder the development and promotion of an innovation-oriented society.

Although we claim on all the channels the desire to recover the gap between us and the West as quickly as possible, the annual investment in research does not reflect this fact. Contrary to some widespread clichés, the main blame for this state of affairs lies with the State. Lack of resources and the small presence of the private sector in terms of investment in research and development emphasizes the gap to the rest of Europe. Moreover, it is considered that the protection of specialized knowledge is one of the roles associated with an organization, [7] but there are not a lot of actions taken to address this.

Intellectual property is one of the main levers of a country's development in all areas. Thus one can appreciate that the protection of intellectual property rights is of great importance the finality being the protection of human intelligence and, at the same time, ensuring that consumers benefit from the use of this product. Closely related to this field is research-development and innovation which constitutes a strategic component, critical to economic development and social progress. Science, technology and innovation are areas that generate constant technological progress while ensuring future economic competitiveness. Innovation and technology transfer must be the solutions to the problems in the economy but also for permanent renewal of the necessary technology by connecting the Romanian research to the demands and pressures of an expanding free market, in the context of globalization.

Table 1: The distribution of patent applications by type of Romanian applicants

\begin{tabular}{|c|c|c|c|c|c|c|c|c|c|c|}
\hline Year & $\begin{array}{c}\mathbf{2 0 0} \\
\mathbf{5}\end{array}$ & $\mathbf{2 0 0 6}$ & $\mathbf{2 0 0 7}$ & $\mathbf{2 0 0 8}$ & $\mathbf{2 0 0 9}$ & $\mathbf{2 0 1 0}$ & $\mathbf{2 0 1 1}$ & $\mathbf{2 0 1 2}$ & $\mathbf{2 0 1 3}$ & $\begin{array}{c}\mathbf{2 0 1} \\
\mathbf{4}\end{array}$ \\
\hline Total applications & $\begin{array}{c}110 \\
0\end{array}$ & 1027 & 926 & 1031 & 1091 & 1418 & 1463 & 1077 & 1046 & $\begin{array}{c}104 \\
0\end{array}$ \\
\hline Resident & $\begin{array}{c}103 \\
2\end{array}$ & 965 & 867 & 995 & 1054 & 1382 & 1425 & 1020 & 995 & 998 \\
\hline Natural persons & 733 & 634 & 533 & 466 & 529 & 567 & 641 & 429 & 495 & 490 \\
\hline Enterprises & 166 & 156 & 122 & 121 & 162 & 135 & 139 & 158 & 151 & 157 \\
\hline Research units & 110 & 127 & 121 & 230 & 222 & 334 & 357 & 208 & 143 & 139 \\
\hline Universities & 23 & 48 & 91 & 178 & 141 & 346 & 288 & 225 & 206 & 199 \\
\hline Non resident & 68 & 62 & 59 & 36 & 37 & 36 & 38 & 57 & 51 & \\
\hline
\end{tabular}

Source: http://www.osim.ro/despre_noi/capitolul_statistici.php

As it can be seen in table 1, the data is updated on the OSIM until 2014, the applications for invention patent coming from universities located on Romanian territory are on an uptrend which means that in the last few years universities, in addition to the involvement in the development of economy and society, and general increase of knowledge (knowledge generation and diffusion of knowledge) have been also actively engaged in activities in the field of intellectual property.

Extrapolating, in Romania, the industries that rely intensively on intellectual property rights, contribute with approximately 45 percent of Romania's GDP, the EU average being 38.6\%, according to a study published last year by the European Patent Office and the Office for harmonization of the internal market in partnership with the European Commission. Romania is 4th in the level of EU GDP of reliance industries that rely on intellectual property rights, with a contribution of more than 55 billion Euros to the Romanian economy in 2010 [8].

Thus, economic growth, social development and enhancing competitiveness, occupy an important role in universities by training young people, stimulating their creativity, stimulating and increasing the awareness regarding intellectual property. Whereas the innovation and technology transfer activity is a transformation process of scientific research results, practical elaborations and/or other technical and scientific achievements leading to new scientific knowledge, products, services, processes, new or improved, which correspond to the practical needs and requirements of the market and who are subjected to the process of technology transfer.

\section{Case study at „Lucian Blaga” University of Sibiu}

Intellectual creation was relevant trough the activities of "Lucian Blaga" University of Sibiu. Organizational concern for stimulating and promoting intellectual creation was influenced by the objective factors-legislative provisions, materials and human resources-but also subjective- such as the 
importance of protecting the managerial vision and enhancement of intellectual creation, the interest degree of authors in protecting original creations.

The Mission of "Lucian Blaga" University overall, of the Administrative Support Structure Intellectual Property Protection (SSAPPI) and of the PATLIB Centre of Sibiu (Sibiu CRPPI) of the European Patent Office and the State Office for Inventions and trademarks is directed toward motivating the enhancement of creative activities (Figure 2), to the development of strategies for the protection of intellectual property, including copyright, the protection and promotion of Sibiu academic inventors and so on [9].

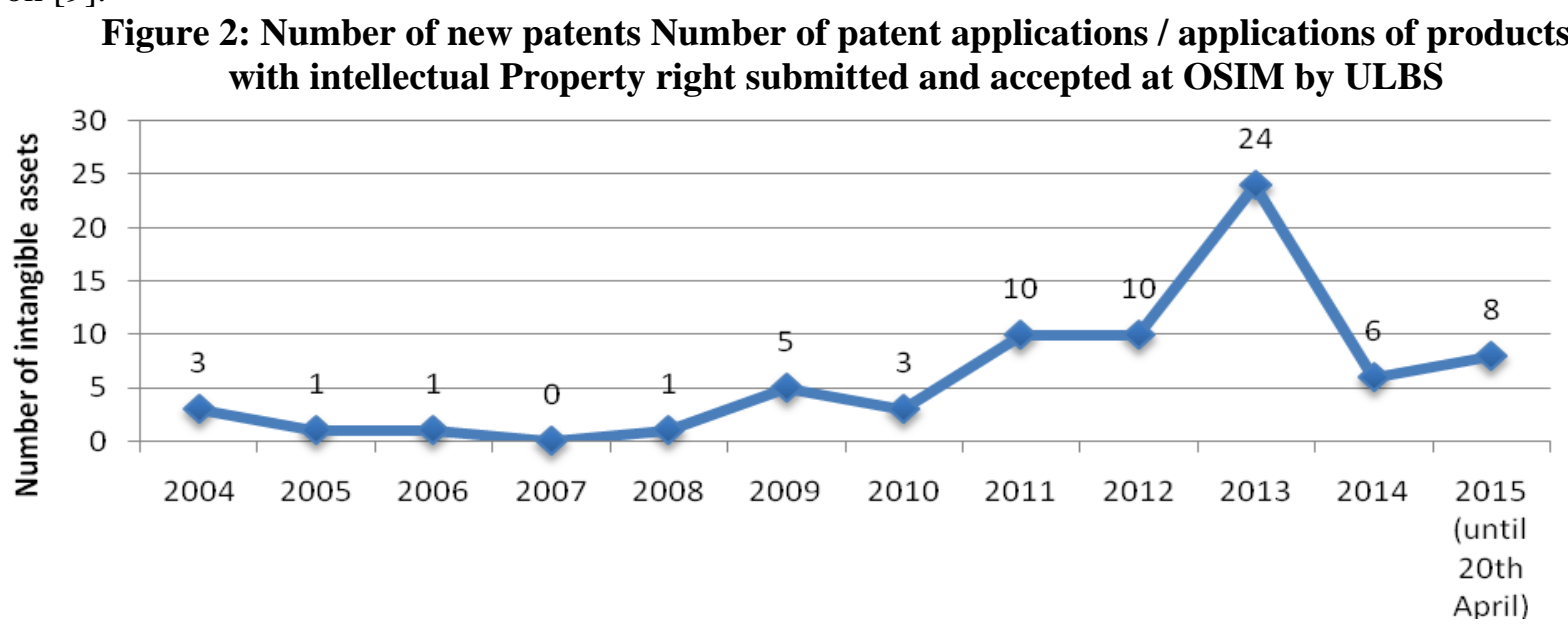

Source: Intellectual property protection report at Lucian Blaga University of Sibiu, 2011-2015, available at: http://ppi.ulbsibiu.ro/ro/despre/rapoarte.php

Currently, the number of inventions proposals and, respectively, the number of patented inventions can be an indicator of the level of a countries development [10]. Unfortunately, overall in Romanian organizations innovation is not regarded as an existing resource to be used in order to grow. Although as shown in Figure 2, the development of creative activity at "Lucian Blaga" University of Sibiu presents an uptrend with oscillations in the year 2014 we cannot affirm strongly that within the University innovation is trained enough or seen as a strategy or a generally adopted way of thinking.

As seen in Figure 1, starting with 2010, the number of intellectual property rights, submitted by ULBS and accepted by OSIM grew, this being due to the establishment at Sibiu of SSAPPI and CRPPI and because of the interest manifested by the people working in these structures in the protection of intellectual property.

Although the approaches for the encouragement of research and creative processes were present at the institutional level, the results show that things can be improved, the strategies reconsidered and that the organizational culture should focus on changing the mentality which promotes physical inactivity.

Another problem that universities are facing is linked to the fact that the relationship with sponsors, who could support creative activity is at an amateur level and the lack of policies to protect their interests in the management of collaborative research activities further accentuates the currently problems faced by the universities[11].

People are the source of innovation and lack of motivation and their resistance to change should be themes taken into consideration by the leaders of the University so that, on long term, can change for better.

It should be kept in mind the fact that ideas are born from communication and innovation was born from discussions between people. The University should set up regular meetings at which thoroughly outlined discussions take place, with well-defined objectives that involve everyone in order to create an environment conducive to the birth of ideas.

Differences with regard to the way in which the theme of intellectual property is addressed in the world are taking shape, also by the fact that while Romanian trainings, courses or study programs in this field are missing or are not very large in number, in other places the students are participating in thematic contests in this area. A fine example is the international OXFORD Debate in the field of intellectual property [12], an international competition involving students from the most prestigious universities.

Romania's desire to be competent regarding the education system should first of all lead to the courses dedicated to teachers and researchers from universities in which they literally learn what intellectual property really means and what is its significance in the society in which it operates. 
Moreover, owing to the potential of people, each student, regardless of the profile they are studying, should deepen a thematic course in this area.

Among the objectives laid down in the field of the protection of industrial property are included the participation in all national and international events, fairs and exhibitions in the field of protection of intellectual property. Analyzing Figure 3 we can say that this objective is achieved through the results, namely the numbers of medals and scientific awards.

Figure 3: Number of medals and other important scientific acknowledgements awarded to ULBS

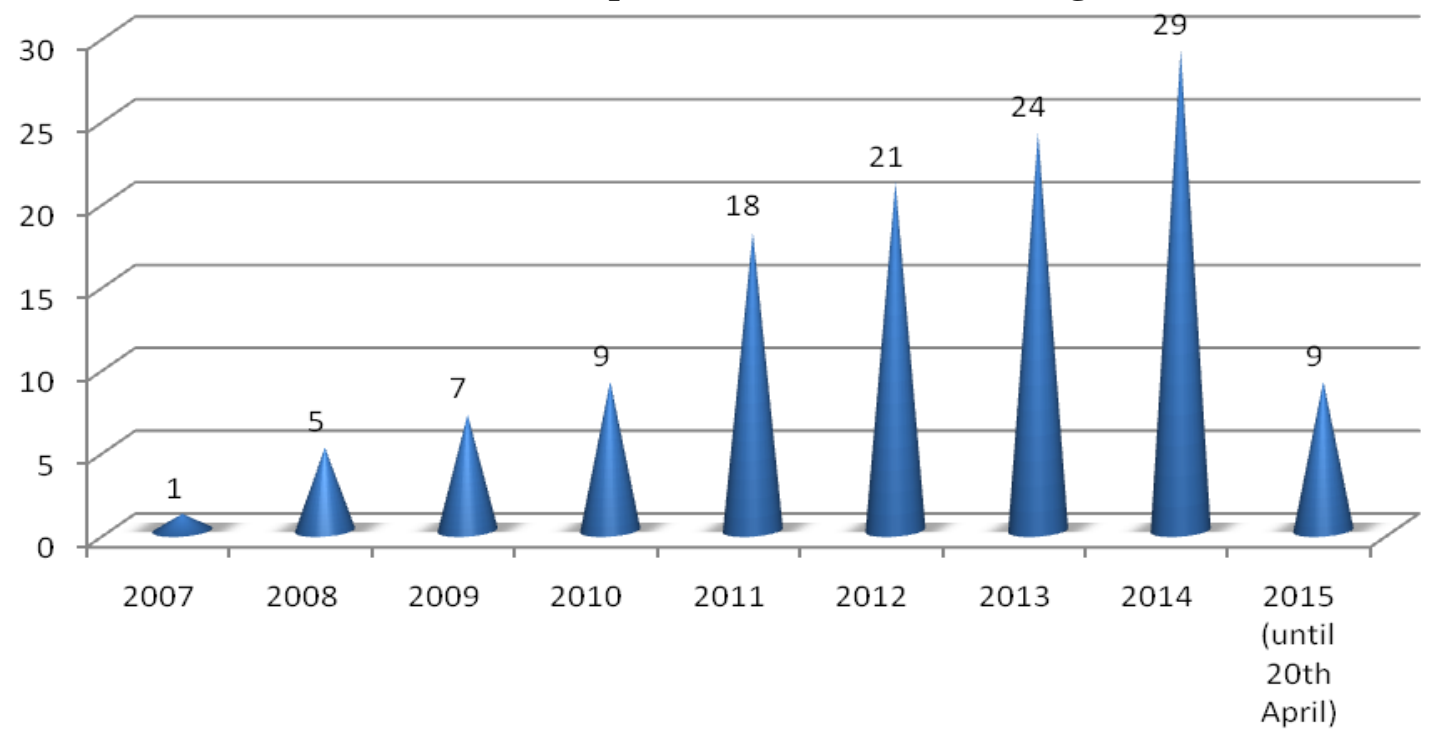

Source: Intellectual property protection report at Lucian Blaga University of Sibiu, 2011-2015, available at: http://ppi.ulbsibiu.ro/ro/despre/rapoarte.php

Paradoxically, the medals taken consistently by Romanian inventors show that there would be enough new products that could enter the serial production. Of course, if they would benefit from the necessary investments and technology development and the needed marketing. Unfortunately, we are at the tail of the European Union as interest for research. Therefore, it is no wonder that we represent only cheap labour for low and medium technology, designed in other countries and this should be a wake-up call that highlights the need for development and training in the field of research.

The present situation emphasizes the need for additional efforts geared toward innovation coming from universities and companies in Romania, a framework conducive to innovation, growth and to provide a relevant experience to the business and academic sectors with regard to innovation. As seen in Figure 4, ULBS in respect of protection of intellectual property rights faculties with applied character are predominant.

Figure 4: Intellectual property rights - ULBS Faculties statistics 2004-2014

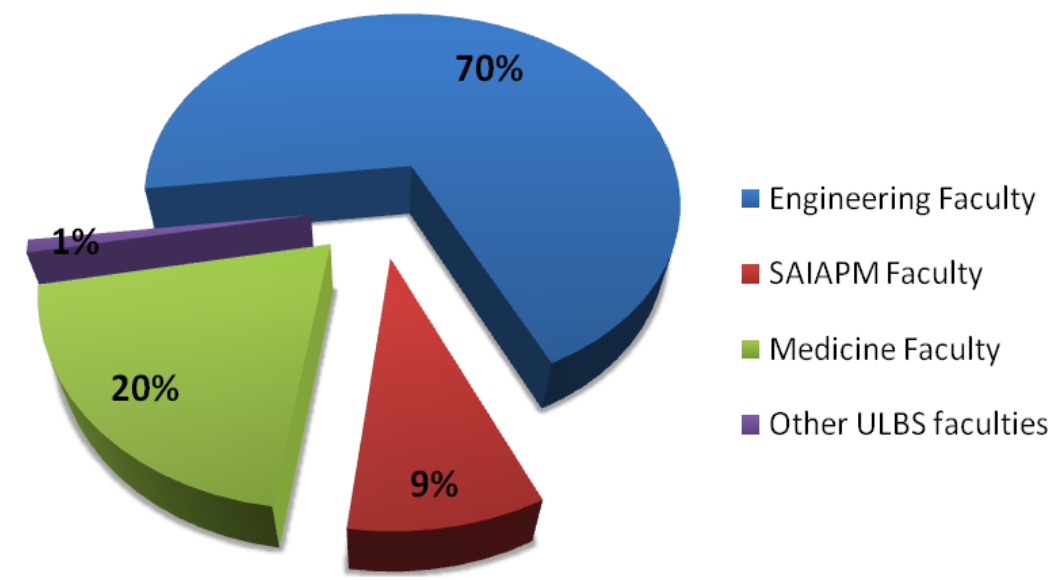

Source: Intellectual property protection report at Lucian Blaga University of Sibiu, 2011-2015, available at: http://ppi.ulbsibiu.ro/ro/despre/rapoarte.php

This is due to the fact that the rest of the faculties, where no one can speak of applicative character, not even interest for the recording of their copyright or related rights, trademarks or industrial designs and models is manifested. 


\section{Conclusions}

Education it is one of the important lessons in innovation, in all its stages. Without constant education at the highest level of professionals in innovation, their results would not be optimal and revolutionary. In the same way, after obtaining innovations the individuals and companies should be educated. The highest level technology needs the educational and advisory side to be known and understood by the target audience, in particular because of the high degree of novelty and complexity.

Innovation means progress, evolution. All companies need innovation to improve the offerings on the market, to develop the business and to become more competitive. Innovation means to bring something new or to improve something existing, essential conditions for development. Starting from this idea, the innovation should not represent a concern just for the technology companies or researchers from diverse fields, but is a duty for each of us. We owe it all to improve permanently, to develop the talents and skills that we have, to optimize living conditions and to bring our contribution to the progress of mankind.

Although innovation is most often perceived as an exclusive concept, approachable only by certain entities, we consider it to be accessible as long as the innovation process is clear and well defined and the organization is able to bring stakeholders creativity to the generation of new ideas, and value.

With regard to innovation in the universities, a major opportunity lies in better management and capitalization of ideas. Sure, such an initiative requires a strategy of innovation management and a reward system dedicated to graduates in order to encourage innovative behavior but the benefits of competitiveness are enormous.

For "Lucian Blaga" University of Sibiu, innovation is not an organizational priority, yet deep in the DNA of the University. In general we can speak rather of passionate individuals who manage to bring innovation on the agendas. Therefore we conclude that without an organization that is ready to innovate at all levels, the chances of success for initiatives and their impact are fairly low. Hence, in the framework of universities the interest for innovation must be maintained at all levels and the creative spirit of each employee has to be revived.

In this regard, we propose a program of periodic training for professors and students to be presented with the theoretical aspects and above all to be driven in the actions for the protection of intellectual property. In the same measure, we consider beneficial to their motivation the recognition of efforts and results at the institutional level.

\section{References}

- Grossman, G.M., Helpman, E. Innovation and Growth in the Global Economy. MIT Press, Cambridge, (1991).

- Murray, F., Stern, S. Do formal intellectual property rights hinder the free flow of scientific knowledge? An empirical test of the anti-commons hypothesis. Journal of Economic Behavior \& Organization 63, 648687, (2007).

- Corrado, C., Hulten, Charles, Dan, Sichel, Intangible capital and U.S. economic growth. Rev. Income Wealth 55 (3), 661-685, (2009).

- Cowan R. \& Harison, E. Intellectual Property Rights in a Knowledge-Based Economy. Paper drawn from the report commissioned by AWT published as AWT Background Study No. 21 (June 2001). MERIT, University of Maastricht, (2001).

- Brealy, N., Intellectual Capital- The New Welth of Organizations, Publishing House, London, pp.11, (1991).

- Hiroyuki, Itami, Thomas W. Roehl, Mobilizing Invisible Assets, Harvard University Press, USA, (1987).

- Tîţu, M, Oprean, C., Boroiu, Al., Cercetarea experimentală aplicată în creşterea calităţii produselor şi serviciilor, Editura AGIR, Bucureşti, (2011).

- Studiu: Mărcile, cele mai numeroase cauze de litigiu de proprietate intelectuală, Forbes România, http://www.forbes.ro/studiu-marcile-cele-mai-numeroase-cauze-de-litigiu-de-proprietateintelectuala_0_10216-15831, accesat la : 11.04.2015

- Țîţu, M., Strategia în domeniul protecţiei proprietăţii intelectuale la Universitatea Lucian Blaga din Sibiu pentru perioada 2011-2015. Disponibil la http://ppi.ulbsibiu.ro/obj/documente/strategia-in-domeniul-ppi-laulbs.pdf, accesat: 04.04.2015.

- Slătineanu, L., Duşa, P., Managementul inovării tehnologice, Editura Tehnopress, Iaşi, (2002).

- Wipo - Guidelines on Developing Intellectual Property Policy for Universities and R\&D Organizations, available at: http://www.wipo.int/export/sites/www/uipc/en/guidelines/pdf/ip_policy.pdf

- $\quad$ http://www.oiprc.ox.ac.uk/moot.php 